\title{
Gercüşlü Fıkra Tipi Üzerine Bir Değerlendirme
}

\author{
Canser KARDAŞ*
}

Öz

Halk edebiyatında anlatmaya dayalı türler arasında en yaygın denilebilecek ve kolay çeşitlenme özelliğine sahip olan tür fikradır. Çoğunlukla nesir olan fikra türü, yoğun ve kısa anlatım özelliğine sahiptir. Sadece dar bir bölgede tanınan fikra tiplerine mahalli tipler denilmektedir. Mahalli fikra tipleri kişi ismiyle veya bir yerleşim adıyla da oluşabilmektedir. Mahalli fikra tipleri, yerelde bilinmesine rağmen verdikleri haz ve güldürme işlevleri bakımından evrensel değer taşımaktadır.

Makalemizde Batman iline bağlı Gercüş ilçesi ve çevresine bağlı olarak oluşan "Gercüşlü” mahalli fikra tipi incelenmiştir. Yörede çok sık olarak anlatılmasına rağmen, söz konusu fikra tipi üzerine bugüne kadar herhangi bir çalışma yapılmamıştır. Günlük hayatta Gercüşlü mahalli fikra tipi etrafında oluşan fikralar, yoğun biçimde Gercüş ve çevresindeki yerleşim yerleri ile Diyarbakır, Siirt, Mardin ve Şırnak gibi çevre illerde de anlatılmaktadır. Gercüşlü fikra tipinin temel özellikleri fikralar referans alınarak açıklanmıştır. Yazıda tipe bağlı olarak oluşan fikraların yapısal, sosyal ve kültürel özellikleri de değerlendirilmiştir. Çalışmada derlenen fikralar arasından yirmi metin seçilerek değerlendirilmiştir.

Anahtar Kelimeler: Mahalli tip, Gercüşlü, Fıkra, Mizah, Gülme.

*Dr. Öğr. Üyesi, Muş Alparslan Üniversitesi, Fen Edebiyat Fakültesi, Türk Dili ve Edebiyatı Bölümü, Muş. Elmek: kardascanser@gmail.com 


\title{
A Review On The Local Of Gerçüş Joke Type
}

\begin{abstract}
Joke is the most common and easy-categorised form among narrative genres in folk literature. Joke narrations which are generally prose, have deep and short narration characteristics. Joke types that are only known in a limited region are called local types. Local joke types can be created either by a person's or a region's name. Although the local joke types are locally known, they have universal value in terms of giving pleasure and amusement.

In this article, local joke type "the local of Gercüş" which was formed in and around Gercüş district of Batman, has been analysed. Although it is told so often in the region where the type still exists, no research has been done yet. In daily life, the jokes which are formed around the local joke type of the local of Gerçüş are extensively told in Gercüş, and in the settlements around such as neighbour provinces Diyarbakır, Siirt, Mardin and Şırnak. The basic characteristics of the type of local of Gercüş are explained by taking jokes as references. In the article, structural, social and cultural characteristic of the jokes are also reviewed based on the type. In this study, twenty texts out of collected jokes are chosen and examined.
\end{abstract}

Keywords: Joke, Local type, The local of Gercüş, humor, laugh 


\section{Giriş}

İnsanların niçin gülmeye ihtiyaç duydukları, neredeyse tüm zamanların filozofları tarafından tartışılan bir konu olmuştur. Platon, Aristoteles, T. Hobbes, Baudelaire, Koestler, Bakhtin gibi çok sayıda filozof, farklı açılardan gülme ve gülmenin kaynağı üzerinde durmuşlardır. Günümüz araştırmacılarından Sanders, yürekten bir gülüşün sağlam hasımları çok kolay devirebileceğini ve tek bir söz söylemeden en büyük zorbanın tehditlerinde dahi gedik açabileceğini belirtmektedir (Sanders, 2013: 33). Bu düşünceyle bağlantıl1 "Gülme devrimci bir eylemdir.” sözü, çoğu zaman günlük konuşmaların sloganı özelliği kazanmıştır.

İnsanlar durup dururken bir şeye gülmezler. Onları gülme eylemine yönelten etkenler vardır. Gülme eyleminde, kullanılan ifadelerin anlam bakımından taşıdığı nükte ve incelik önemlidir. Nükte ve inceliği barındıran beklenmedik cevap veya cevaplar, dinleyen kişilerde gülme eylemini sağlayabilir. Diğer taraftan bir fikranın başarılı sayılabilmesinin ölçütlerinden biri şaşırtarak güldürebilmesidir. Fıkra ne kadar nitelikli olursa olsun fikrayı anlatan kişinin anlatım tekniği konusunda uzman olması gerekmektedir. F1kra anlatılırken anlatıcının ses tonu kadar jest ve mimiklerini iyi kullanması da fikrayı kaliteli kılan diğer bir etkendir. Fıkranın amacına ulaşabilmesi için anlatıcının zamanı, mekânı ve dinleyicileri diğer bir ifadeyle bağlam özelliklerini göz önünde bulundurması gerekir. Türk Dil Kurumu sözlüğünde gülmeye dair açıklama şu şekilde verilmiştir: "Gülme: gülmek işi, kahkaha"; "gülmece: 1.eğlendirmek, güldürmek ve birine, bir davranışa incitmeden takılmak amacını güden ince alay, mizah, humour. 2. Gerçeğin güldürücü yanlarını ortaya koyan edebiyat türü, mizah"; “mizah: gülmece” şekillerinde tanımlanmaktadır.

Hiciv, şathiyat, zevkiyat, mutâbeyat, mudhike, fikra, nükte, lâtife ve espri gibi sözcüklerin mizah anlamı taşıdığını vurgulayan Yücebaş, herkesin zekâ düzeyine göre mizahın etkisinin değiştiğini, aynı zamanda lastikli ve değişken bir konu olduğunu belirtmektedir (Yücebaş, 2004: 11). Mizahın kalitesi ne olursa 
olsun kişinin zekâsıyla mizaha kattığı anlam, gülme eyleminde önemli rol oynayabilmektedir. Fikra gülme için özel bir etki yaratmakta ancak bilgi nakletme amacı taşımamaktadır.

Gülme eylemi insani davranışların bir sonucudur. Bu hususta Bergson, filozofların yaptığı "gülmesini bilen bir hayvan" açıklamasına itiraz ederek, insana aitlik dışında hiçbir şeyin gülünç olamayacağını iddia etmektedir. Bergson'a göre, kişinin bazen bir hayvana, bir peyzaja veya bir nesneye gülebilmesine, taşıdığ insani özellik veya davranış yol açmaktadır (1989: 14).

Gülmecenin konusunu gündelik hayat olayları, gölge oyunları, fikralar, sinema, modern tiyatro vb. oluşturmaktadır. Gülmecenin başlıca konularından birini teşkil eden fikralar, akla gelebilecek her çeşit söz sanatını içermekte ve milletlerin kültür varlıklarını belirleyen yapıları yansıtmaktadır (Özünlü, 1999: 94).

Eğlencenin hoşgörülü ve esnek ortamı her türlü espri, fikra ve şakanın rahatlıkla yapılabilmesine olanak verir (Özdemir, 2005:162). Toplantılarda, çeşitli ortamlarda soğuk ve resmi havayı dağıtmak veya sıcak bir ortamın oluşturmak için başvurulabilecek en kolay yollardan biri fikra anlatma olarak değerlendirilebilir.

F1krayı diğer türlerden ayıran önemli unsurlardan biri, gündelik hayata giren teknolojik ürünlerin fikrada yer almasıdır. Radyo, televizyon, telefon, bilgisayar, uçak ve motorlu taşıtlar gibi teknolojik ürünler fikralara zenginlik katan unsurlardandır (Şimşek, 2015: 198). Bu şekilde tarihi bir fikra tipi bilgisayar kullanabilmekte veya uçağa bindirilerek günlük hayat sahnelerine eklenmektedirler. F1kralar çoğunlukla politik, ekonomik, toplumsal ve kültürel davranışlara ters düşen herhangi bir durumla ilgili olabilmektedir. Bu yönüyle fikralar toplumun eleştirisi/özeleştirisi şeklinde kabul edilebilir. Boratav, herhangi bir düşünceyi örnek vererek güçlendirmek, karşısındakini ona inandırmak ya da direnişinde yanıldığına tanık göstermek, herhangi bir durumu açıklamak amacıyla fikraya başvurulduğunu belirtmektedir (2013: 94).

Türk Dil Kurumu Güncel sözlüğünde fikra, "Kısa ve özlü anlatımı olan, nükteli, güldürücü hikâyecik" şeklinde tanılanmaktadır. F1kra türüyle ilgili Pertev Naili Boratav (2013: 85), Şükrü Elçin (1986: 566) ve Dursun Yıldırım (2016: 36) başta olmak üzere çok sayıda araştırmacının yaptıkları tanımlar fikranın farklı 
açılardan anlaşılmasını kolaylaştırmaktadırlar. Özellikle Dursun Yıldırım, fikranın bütün özelliklerinin yer aldığı kapsayıcı ve güzel bir tanım yapmıştır.

"Hikâye çekirdeğini hayattan alınmış bir vak'a veya tam bir fikrin teşkil ettiği kısa ve yoğun anlatımlı, beşeri kusurlarla ictimai ve gündelik hayatta ortaya çıkan kötü ve gülünç hadiseleri, çarpıklıkları, zıddiyetleri, eski ve yeni arasındaki çatışmaları sağduyuya dayalı ince bir mizah, hikmetli bir söz, keskin bir istihza yoluyla yansıtan; umumiyetle bir fikra tipine bağlı olarak nesir diliyle yaratılmış, sözlü edebiyatın müstakil şekillerinden ibaret yaygın epik-dram türündeki realist hikâyelerden her birine verilen isimdir." (2016: 36).

Birer nükteye dayanan fikralar ve latifeler anlatım bakımından hikâye, gülünçlük yönünden de gülmece karakteri taşıdığını belirten Levend, fikra ve latifelerin içerik açısından da üç şekilde değerlendirilebileceğini belirtmektedir. $\mathrm{Bu}$ üç değerlendirme şeklinden birincisi büyüklerden birinin hayatını ve karakterini canlandırır; ikincisi topluluklardan birinin özelliklerini yansıtır; üçüncüsü ise hiçbir kişiye değinmeden insanoğlunun acınacak, gülünecek ruh halini, telaşlı durumunu belirtir (Levend, 1984: 156).

Halkın ortak zevk ve estetik anlayışından doğan fikra, insanların gündelik hayatın acı, tatsız ve sıkıntılı anlarından uzaklaşmak için başvurdukları bir türdür. Fıkra, halk felsefesinin ruh bulduğu türdür. Fıkralar mahallî, tarihi bir kişilik, bir zümreye bağlı veya anonim bir tipin merkeze alınmasıyla oluşmaktadır.

Diğer edebi türlere göre günlük hayatta en yaygın bulunan ve kullanılan tür fikradır. Anlatılacak fikra seçilirken bağlam mutlaka göz önünde bulundurulmaktadır. Fıkralar rastgele anlatılmaz çoğunlukla yaş grubu, cinsiyet ve bulunulan ortama göre farklı içeriğe sahip fikralar anlatılmaktadır. Dini, sosyal, ciddi, müstehcen veya gündelik hayatla ilgili fikralar anlatılırken ortam ve dinleyici dikkate alınarak seçilir. Fıkranın günlük hayatta çok yaygın olarak başvurulan bir tür olmasının gerekçelerinden biri de kısalığı ve günlük dilin kullanılmasından dolayı ezberinin kolay olması ve duruma uygun bir ortam oluştuğu anda anlatılmasını da kolaylaştırıyor olmasıdır. Bu anlamda "taşı gediğine koymak" deyimi fikrayı pek çok yönüyle açıklama özelliğine sahiptir. Fıkrada anlatım kolaylığının kaybolmaması için gereksiz tasvir, kişi ve ayrıntılar yer almaz.

Yazıya aktarılan fikraların bazen sözlü kültürdeki aynı anlam ve zenginliği 
yakalaması güç olmaktadır. Çünkü kimi fikralar anlatılırken vurgu ve tonlamalar fikraların anlaşılmasında önemli işlevlere sahiptir. $\mathrm{Bu}$ vurgular tam anlamıyla yazıya aktarılamadığından fikrada verilmek istenen mesaj eksik olmakta ve başarılı bir fikra olmaktan çıkmaktadır.

Anadolu mahalli fikra tipleri üzerine yapılan doktora çalışmasında da Mardin'de ${ }^{1}$ bulunan yerel tipler arasında Gercüşlü tipi sayılmamıştır (Altunel: 1990). Bundan dolayı bu çalışmanın yapılması gerektiği kanaati ortaya çıkmış ve bu alanda yapılan çalışmalara katkı sunacağı düşünülmüştür.

\section{Gercüşlü Fıkra Tipinin Özellikleri}

Yazılı ve sözlü edebiyatta bir sosyal çevre veya zümrenin belirli bir davranış biçimini temsil etme yeteneği kazanan kişiye tip denilmektedir (Aça, 2010: 639). Sözlü edebiyatta tipleşmenin oluşabilmesi belli bir döneme yayılmasına bağlıdır. Tipleşmenin gerçekleşmesinde dar bir yöre, bir bölge veya ulusal bir çevrede genel kabul görmesinin yanında günlük hayatta yoğun olarak işlenmesi gerekmektedir.

Öte yandan bir yörenin ekonomik ve toplumsal yapısı ile yaşam koşullarının etkisiyle yöre insanı benzer olaylar karşısında ortak tepkiler verebilmektedir. Ortak tepkiler yerel düzeyde fikra tiplerinin oluşmasını sağlamaktadır. Böylece mahalli tipler alışılmış davranış kalıplarından farklı olarak gösterilen tepkilerle kimlik kazanır.

Boratav mahalli fikra tipini, "Farklı 'kavmi' asıllardan toplulukların birbirleri üzerine ya da herhangi bir bölge, bir kasaba, bir köy halkının başka bir bölge bir kasaba ya da bir köy halk üzerine anlattıkları hikâyeler de ayrı bir çeşit meydana getirirler; bunlar bir toplumun kendinden olmayanları, onların saflıklarıyla tuhaflıklarıyla alay edip gülme amacıyla uydurulan hikâyelerdir" şeklinde açıklar (2013: 103).

Artun, mahalli tipi "belirli bir coğrafya üzerinde yaşayan insanları temsil eden ve bağlı oldukları mekânla isimlendirilen bölge ve yerel fikra tipleri" şeklinde açıklamaktadır (2013: 15). Ancak farklı coğrafyalarda benzer olaylar karşısında ortak davranışlar sergilenebilmektedir. Bu durumda kişi, yer adla-

1 Adı geçen tezin hazırlandığı 1990 yılına kadar Gercüş ilçesi Mardin iline bağlı bir ilçedir. 16.05.1990 tarihinde Batman'ın il olmasıyla Batmana bağlanmıştır. 
rı ve yörenin özellikleri ilgili bölgede tanınan yeni bir tipe uyarlanarak geçmektedir. Anlatı icra edildikçe adaptasyonda başarı artmaktadır. Sakaoğlu, bu durumun geleneksel fikralarda kolaylıkla gerçekleşebileceğini ve bunun geleneksel fikraların başlıca özelliği olduğunu belirtmektedir (Sakaoğlu, 2013: 72). Şimşek, bir fıkranın anlatıldığı bölgenin sosyal ve etnografik şartlarına bağlı olarak değişiklik gösterebildiğini ve benzer özellikler gösteren başka bir tipe kolaylıkla mal olduğuna sıkla karşılaşılan bir durum olduğunu belirtmektedir (Şimşek, 2006: 259). Gercüşlü fıkra tipine bağlı olarak anlatılan fikraların bir kısmına başka bölgelerde de karşılaşmak mümkündür. Birinci örnekteki berber fikrasının küçük farklılıklarla Çukurova çevresinde de anlatıldığı bilinmektedir (Artun, 2013: 35).

Çalışmamızda değerlendirdiğimiz Gercüşlü tipi yapılan tasniflerden, Yıldırım'ın "Bölge ve Yöre Tipleri” alt başlı̆̆ı, Sakaoğlu'nun ise "Sadece Yaşadıkları Bölgede Tanınan Tipler" alt başlığında değerlendirilebilir. Bu tip, şehir ismiyle bütünleşmiş ve bu şekliyle tanınmıştır (Yıldırım, 2016; Sakaoğlu, 1992).

Altınel fikranın "en belirgin özelliği ister maddi kültür sahasında isterse manevi kültür sahasında olsun hem doğduğu milletin malı hem de dünyanın aynı bölümünde yaşayan milletlerin ve halkının ortak malıdır.” şeklinde belirtmektedir (1990: 10). Bu anlamda tip yörede hangi dilde anlatılırsa anlatılsın genel bir sahiplenme olduğu ve ağalıkla ilgili olduğu düşünülen davranışlar ile araçlarda "öne oturma" önemli oranda halk tarafından sahiplenildiği anlaşılmaktadır.

Mahalli fikra tiplerinde açıkgöz, bilgili, bilgisiz, uysal, vurdumduymaz, utangaç, atak, şaşkın, kurnaz, korkak, atılgan gibi çelişik durumlar bulunur (Artun, 2013: 16). Benzer durumları Gercüşlü tipinde de görmek mümkündür. Gercüşlü fikra tipi, fıkralarda çoğunlukla olaylar karşısında doğal davranışları, gariplikleri, saflıkları, rahatlıklarına düşkünlükleri gibi özellikleriyle yer alırlar. Bu özellikler farklı şekilde karşımıza çıkmakla beraber Gercüşlü fikra tipinin iki şekilde tipleşmeye doğru evrildiği görülmektedir. Gercüş merkezle ilgili fikralarda ağalık özellikleri ön plandayken merkez dışında kalan yerleşim yerlerindeki Gercüşlü tipinde ise saflık temel özellik olarak görülmektedir.

Gercüşlü tipi fıkralar; göç olgusu, iktisadi ilişkiler ve üniversite eğitimi sırasında öğrencilerin kurdukları iletişim aracılığıyla yayılmaktadır. 
F1kralar doğaları gereği gerçekçidirler. Gercüşlü mahalli tipine bağlı olarak oluşan fikralarda yer alan kişiler toplumun yapısına bağlı olarak günlük hayatta var olan esnaf, çoban, köylü, imam, bakkal veya işsiz şeklinde karşımıza çıkmaktadır. Çalışmamıza konu olan fikraların genel özellikleri aşağıdaki gibi sıralanabilir.

-Kendini önemli hissetme/hissettirme (2-8)

-Gururlu olma, eksikliklerini dişarıya hissettirmeme (3-4-10)

-Değerli biri olmak araçlarda önde oturmayı gerektirir (5-18)

-Kendini ağa olarak görme (13-14-15-17)

-Çabuk kanma (6)

-Saf köylü (7-11)

-Tarihsel olay (9)

-İnanç (20)

-Kendini beğenme (16)

-Açıkgözlük, pişkinlik (16)

\section{Yapısal Özelikleri}

F1kra, normal şartlarda giriş, gelişme ve sonuç bölümlerinden oluşmaktadır. Gercüşlü tipi fikralarının bir kısmında bu şekil aynen korunuyorken önemli bir kısmında ise giriş ve gelişme iç içedir. Anlatım ise çok yoğun bir şekilde işlenir. Gercüşlü tipi etrafında oluşan fikralarda ders vermekten ziyade eğlendirme ve güldürme özelliğinin ağır bastığı görülmektedir.

Gercüşlü tipindeki fıkralarda tasvir çok sınırlı, ayrıntılar ise yok denecek kadar azdır. Fıkranın ayrıntıları barındırmaması veya çok kısa olması anlamında herhangi bir kayba yol açmamaktadır. Gercüşlü tipine ait fikraların tamamı çoğu zaman söylenmese de verilmek istenen mesaj, başarılı bir şekilde aktarılabilmektedir. Zaman açısından bakıldığında ise bazen zaman belirsiz bazen de tarihsel olaylar ile bağlantı kurulduğundan tarihler belirgin olmaktadır.

Gercüşlü fikra tipi, döneme göre değişim göstermektedir. Ancak merkezle bağlantılı anlatılan fikralarda değişmez temel unsur "ağa" motifidir. Gercüşlü olup bağlı yerleşim yerlerinde yaşayanlar ise Gercüşlü tipi olarak tamamen form değiştirip saf bir kişiliğe bürünür. Bu farklılığın yanında ortak olan davranış kalıbı ise Gercüşlü tipin araçların ön koltuğuna oturma isteğidir. 


\section{1. Şahıslar}

F1kralarda bir olay ve bu olayla ilişkili kişiler yer alır. Gercüşlü fikra tipinde bulunan kahramanlar mesleği ve toplumdaki konumu ne olursa olsun tip olarak yer alabilmektedir. Dolayısıyla Gercüşlü tipinde kahraman bir meslek grubu, aile, yönetici veya din ile ilgili kişilerden herhangi biri olabilir. Fıkra karakterleri ağa, tüccar, işsiz, çoban, kirac1, ev sahibi, memur gibi kişilerden oluşur. Ancak karakterden ziyade vali, şoför gibi sadece ismi bulunan kişiler de bulunur.

Gercüşlü fikra tipinde yer alan şahıslar, günlük hayatta her an karşımıza çıkabilecek gerçek kişilerdir. Bu tip iki şekilde tipleşmeye doğru gitmektedir. Birincisi şehir merkezinden olup ağalı̆̆ın ön planda olduğu, ikincisi ise Gercüş köylüsünü temsil eden ve saflğın ön planda olduğu tiptir.

3.1.1. Ağa: F1kralarda geçen "ağa" tipi; toprak zengini, yanında maraba çalıştıran ve ahaliye zulüm eden tip değildir. Rahatına düşkün, ekonomik gücü olmamasına rağmen asaletine gölge düşürecek işlerden kaçınan bir tiptir. Bu tip Gercüş merkezinde yaşayanlarla bağdaştırılan tiptir. Bu tipin fikra tipine göre en önemli özelliği seyahatlerde en önde oturması ya da oturmak istemesidir. Öyle ki önde oturamadıklarında zor kullanarak arabanın geri sürdürülmesi fıkra örneğinde olduğu gibi karşımıza çıkabilmektedir.

Gercüş çevresinde 1srarla araçlarda öne oturmak isteyenler olduğunda fikra tipinin etkisiyle “Sen Gercüşlü müsün?” sorusuyla sık sık karşılaşılmaktadır. Yine günlük hayatta ağır işlere koşmayan veya iş beğenmeyenler olduğunda "sanki Gercüşlü” ifadesi sık sık duyulmaktadır. Bu açıdan bu özellikler tüm Gercüşlülere has bir davranışmış gibi bir algı oluşturmuştur.

3.1.2. Köylü: Köylü merkezli fikralar, merkezde oturanların köylülerle ilgili oluşturduğu fikralardır. Çalışmamamızda yer verdiğimiz iki fikranın, şehirlilerin köylülere bakış açısını sergilemesi bakımından önemli olduğu düşünülmektedir. Tarafımızdan yapılan çalışmalarda Gercüşlü “ağa” tipinin merkezde olduğu ve köylüleri konu alan bir fikra tespit edilememiştir.

Esas olarak kentlilik ve köylülük tartışmalarının yoğun olduğu her şehirde köylüleri hor gören fikra sayısının kabarık olduğu bilinmektedir. Bu tarz tartışma ve fikralar çoğunlukla tarihi bir kimliği olan şehirler ile daha sonradan şehre yer- 
leşen köylüler arasında yoğundur. Bu şekilde (7) numaralı fikrada yer alan köylünün sisi deniz olarak algılaması ve bunun sonucunda yük ve eşeklerinden vazgeçmesi; aynı şekilde (11) numaralı fikrada da köylünün şalgamlarını yiyen eşeğini tokatlaması ve kulağını 1sırması, bunun somut göstergesi olarak kabul edilebilir.

3.1.3. Çoban: Çoban karakteri iki fikrada (14-15) karşımıza çıkmaktadır. Mesleklerinin çobanlık olması Gercüşlü ağa tipini temsil etmelerinin önünde bir engel olarak görülmemektedir. Çoban tipi 14 ve 15 numaralı fikralara bakıldığında doğrudan kendisini ağa olarak kabul etmekte ve yaptırımlardan kurtulmak için şehirden ayrılmayı düşünmektedir.

3.1.4. Tüccar: Meslek gruplarından olan tüccar üç fikrada karşımıza çıkmaktadır. 10 numaralı fikrada tüccar, işsiz olanların "ağa" olamayacağı imasıyla onları çalıştırmak istemesi ve bunu kabul etmemeleri şeklindedir. 6 ve 19 numaralı fikralarda ise zor durumda kalan tüccarların Gercüş’te konaklamak zorunda kalmasıyla ilgilidir. Gercüşlü fikra tipinin özelliği olan "çabuk kanma" 6 numaralı fikrada göz açık tüccarın kolaylıkla konaklamasını sağlıyor. 19 numaralı fikradaki tüccarın bu özelliği bilmemesi, onu konaklamak üzere "tanrı evi”ne yönlendirilmesine neden olmuştur.

Gercüş ve çevresinin birinci derece geçim kaynağı tarımdır. Hayvancılık ikinci derece geçim kaynağı olduğundan hayvan konulu fikralar çok azdır. Fıkralarda karakter olarak yer almasa da rolleri olan hayvanlar bulunmaktadır. Dört fikrada hayvan isimleri geçmektedir. Eşek (7-11-12), inek (12) ve arı (13) nolu fikralarda yer almaktadir.

\subsection{Mekân}

Gercüşlü tipi fikralarında mekân gerçek dünyadır. Gercüşlü tipine bağlı olarak oluşan fikralarda fantastik unsurlar bulunmaz. Bu fikra tipi çerçevesinde oluşan fikralarda asıl mekân Gercüş’tür. Ancak çevre şehirler de bu tipe mekân olabilmektedir. Mekân olarak Gercüşlü fikralarında şehir, köy, bağ, dükkân, berber dükkânı, kahvehane, mağaza, ev, bina, camii, dinlenme tesisi gibi yerler karşımıza çıkmaktadır.

F1kraların çoğunda da görüldüğüu üzere mekân bellidir. Gercüş'ün, (2-3-68-9-10-11-12-13-14-15-17-19) numaralı fikralarda mekân olarak kullanıldığı gö- 
rülmektedir. Batman (16), Beşiri (7), Suudi Arabistan [Hac] (4) fikraların geçtiği diğer mekânlardır.

Fıkra tipinde mekânın belirsiz olduğu fikralar da bulunmaktadır. Bu şekildeki fikralardan ikisi (1-5) makaleye alınmıştır. Ancak mekânı belirsiz fikra fazla bulunmamaktadır. Fikralarda mekân olarak kullanılmayan ancak ismi geçen şehirler ise Siirt (7), Ankara (18), köyler (11-20) ve Mardin (15)dir.

\subsection{Zaman}

F1kra türünde genel olarak zaman belli değildir. Gercüşlü tipi çerçevesinde oluşan fikraların önemli bir kısmında da zaman belirli değildir. Bunlar "Bir gün" şeklinde başlar ve dönemini belirlemek mümkün değildir. Ancak incelediğimiz fikraların bir kısmında ise zaman belirgindir. Hatta kimi fikralarda tarih verilmezse de siyasi bir olayla bağlantılandığından yılları tespit etmek mümkün olabilmektedir.

Fıkraların tamamı Cumhuriyet döneminde yaşanmıştır. Kimisinde olay zamanı netken, kimisinde mevsimsel ya da dönemsel olarak bellidir. İncelenen yirmi fikrada zaman bakımından fikraları üç gruba ayırmak mümkündür.

\subsubsection{Zamanı kesin olarak belli olan fikralar:}

-"Gercüş’te yakın tarihte ilk on katlı bina yapıldı. [2005-2007]" (8)

-“Şeyh Said isyanı zamanında...”(9)

-“1980-1990’lı yıllarda Gercüş’te işsizlik had safhadadır.”(10)

\subsubsection{Zamanı (Yılları) belli olmayan ancak dönemi/mevsimi belli olan fikralar: \\ -“... Gercüş’ün merkezine gelince temmuz sıcağında şoför camları kapat- miş." (3) \\ -“On iki kişilik bir grup hacca gitmiş. [Hac dönemi]”(4) \\ -“Gercüşlünün biri pekmez yapmış ve Siirt’e götürmek üzere...[Sonba- har]”(7)}

-“Gercüş’ün bir köyünden bir adam birkaç sepete şalgam yüklemiş, Gercüş'e getiriyor.[Yaz]”(11)

-“Üzüm zamanıdır.[Yaz-Sonbahar]”(13) 
3.3.3. Zamanı belirsiz fikralar: Yukarıda gösterdiğimiz fikralar dışında kalan fikraların zamanı belirsizdir. "Bir gün... (14-15)" şeklinde ya da her an yaşanabilecek hissi veren "Gercüşlüler arabaya bindikleri zaman..." şeklinde zamanı/zamansızlığı belirten fikralardır.

\subsection{Dil ve Üslup}

Gercüşlü fikra tipine bağlı anlatılan fikralarda dil ve üslup özellikleri Gercüş dışında anlatıldığından Gercüş çevresinin özelliklerinden ziyade farklı bölge özelliklerini yansıtır. Fıkralar; Kürtçe, Türkçe ve Arapça gibi yörenin günlük konuşma dillerinde anlatılmaktadır. Aynı fikranın farklı dillerde aktarımı verilmek istenen mesajda bazen eksikliklere yol açabilmektedir.

Üslup özelliklerine bakıldığında ayrıntılı tasvirler hiç bulunmaz. Kısa ve yoğun anlatıma sahip bazı fikralar argo ${ }^{2}$ ifadeler de barındırmaktadır.

\subsection{Sosyo-Kültürel Özellikler}

Halk edebiyatının özelliği itibariyle her ürün oluştuğu bölgenin kültürel özelliklerini birçok yönüyle içinde barındırmaktadır. Bu açıdan bakıldığında Gercüşlü fikra tipine bağlı olarak oluşan fikralar, farklı bir bölgede anlatıldığında aynı derecede gülünç olarak görülmeyebilir. Bergson, komik şeylerin birçoğunun bir dilden diğerine çevrilemediği, çünkü ayrı bir cemiyetin adetlerine, fikirlerine tercüman olduğunu belirtmektedir (1989: 16). Aynı şekilde "Uyumsuzluk Kuramı"na göre Morreall da farklı kültür insanlarının bir anlatıda (=fikra) uyumsuz davranışları bulamamalarına yol açacağını ve gülünç unsurların zor yakalanabileceğini vurgulamaktadır (1997: 90). Dolayısıyla kimi fikra örnekleri yörede çok gülünç görülmesine rağmen farklı bölgelerde gülünç olarak değerlendirilmemektedir.

Yukarıda belirtildiği üzere fikraların yörenin farklı konuşma dillerinde anlatılması bazen anlamın korunmasını güçleştirmekte ve anlamda değişime yol açmaktadır. Ancak farklı dillerde aktarımın fikraya zenginlik kattığı da söylenebilir.

Sosyal hayat çok yönlü olarak fikralarda yer alır. Yöre insanı her ne kadar "Gercüşlü Ağa" tiplemesiyle ünlenmiş de bir eşek yükü odunu (Örnek 17) satmaya gitmesi veya bir y1llık emeğin ürünü olan kuru üzüm ile pekmezi ya da şalgamı 
günlük olarak (Örnek 7-11) eşeklerle çevre şehirlere satmaya gitmesi ekonomik olarak yörenin güçlü olmadığının göstergesi olarak değerlendirilebilir.

Sosyal hayatın şekillenmesinde en önemli unsur dindir. Tespit edilen fikralardan dini içerikli sadece bir tane (Örnek 20) tespit dilmiştir. Din görevlisinin halkın yapmasına karşı çıktığı uygulamaların kendisinin yapmasını yerdiği görülmektedir.

Sadece sanatta ve edebiyatta değil, sosyal yaşamın da içinde olan mizah, gündelik söylemin bir parçasını oluşturmaktadır (Altıntop, 2017: 12). Güzel sanatların tümünün yanında sosyal hayat birçok yönüyle mizaha konu olabilmektedir. Gercüşlü tipine bağlı fikralar günlük olaylar ile toplumun tarihsel-toplumsal koşullarına bağlı olarak oluşmakta/değişmektedirler.

Derlenen fikralarda kadınlar karakter olarak çok az görünürler. Sadece 6 numaralı fikrada evin hanımı olarak karşımıza çıkmaktadır. Gercüş ve çevresi aşırı kapalı bir yapıya sahip olmamasına rağmen, kadınlar fikralarda kendilerine yer bulamamışlardır.

Gercüşlü fikra tipine bağlı olarak oluşan fikralarda karakterlerin aksine, Gercüş’te eğitim seviyesinin uzun yıllardan beri yüksek olduğu ve eğitime de önem verildiği bilinmektedir. Buna rağmen Gercüşlülerin bu yönü fikralara yeterince yansımadığı görülmüştür.

Gercüş ve çevresinde temel geçim kaynağı tarımdır. Örneklerden de anlaşılacağı üzere bağcılık temel geçim kaynağıdır. Sosyal hayat ve ekonomik yapı olduğu gibi fikralara yansımıştır.

\section{Sonuç}

Sözlü ürünlerin kalıcıllğının temel koşullardan biri, toplumun bireyleri tarafından kabul edilip anlatılıyor olmasıdır. Araştırma alanımızı teşkil eden Gercüş’te bu sözlü ürünlerden fikralar, toplumsal hayata bağlı olarak oluştuğundan pek çok yönüyle Gercüş'ün sosyal ve ekonomik hayatından izler barındırmaktadır. Ancak bu fikra tipi Gercüşlüler tarafından anlatılmaz çevredeki yerleşim birimlerinde Gercüşlülerle ilgili anlatılır. Gercüşlüler kendileri bu fikraları anlatmasa da çevrelerinde bu ürünlerin anlatıldığının farkındadırlar. 
Sözlü kültür ürünlerinin çoğu gibi fikralar da sürekli bir değişim geçirmek ve yeni hal almak suretiyle varlıklarını devam ettirmektedirler. Gülünç, saflık veya hazırcevaplık gibi konularda sürekli Gercüşlü tipine uyarlanarak yeni metinler oluşturulmaya devam edilmektedir. Buna 8 ve 11 numaralı fikralar örnek verilebilir.

Gercüşlü fikra tipine bağlı oluşan fıkraların hiçbirinde olağanüstü kişi ve olaylar yer almaz. Aslında fikra tipleri, bir toplumu simgelediğinden bu fikra tipine bağlı oluşanları kısmen Gercüşlülerin genel davranış özellikleriyle örtüşmektedir.

F1kraların çoğu tek olaya bağlı olarak oluşmuştur. Sadece dört tane fikrada birden fazla olay vardır. Ayrıca fıkranın uzunluğu ya da kısalığının olay sayısı ile ilgisi bulunmamaktadır. Amaç konunun daha net anlaşılmasını sağlamaktır.

Gercüşlü fıkra tipine bağlı olarak derlenen fıkralarda güldürme ve eğlendirme işlevi ön planda yer alır. Düşündürme ve eğitme işlevi ise çok sınırlıdır.

F1kralardaki olaylar gündelik yaşamın kısa sahneleri şeklindedir. Olayların zamanı ve mekânı çoğunlukla bellidir. Gercüş merkez ana mekân olmak üzere çevre köy ve şehirler fikraların geçtiği yerlerdir.

Bazı fikralarda tarihi olaylar da konu edinilmektedir. 9 numaralı fikrada Şeyh Said olayına atıfta bulunularak ağalarla ilişkilendirilmiş ve fikra oluşturulmuştur.

F1kralardaki tip özelliklerinin bir kısmı halkla uyumlu iken önemli bir kıs$\mathrm{m} ı$ ise çevrede yaşayanların değer, davranış gibi farklı özellikleri Gercüşlü tipine mal edilerek onlar üzerinden aktarmaya çalışmışlardır. 


\section{Kaynakça}

Aça, Mehmet-Metin Ekici-A. Müge Yılmaz (2014). Anonim Halk Edebiyat1, Türk Halk Edebiyatı El Kitabı.(Edt. Öcal Oğuz) Ankara: Grafiker Yayınları.

Aça, Mustafa (2010). Türk Mahalli Fıkra Tiplerine Bir Örnek: İssiyin ve Sümes, Uluslararası Giresun ve Doğu Karadeniz Sosyal Bilimler Sempozyumu Bildirileri. C. II, Giresun belediyesi yayınları.

Altıntop, Gülden (2017). Karikatür, Edebiyat, Söylem, (Yayınlanmamış Yüksek Lisans Tezi) Mardin Artuklu Üniversitesi, Sosyal Bilimler Enstitüsü, Mardin.

Altunel, İbrahim (1990). Anadolu Mahalli Fıkra Tipleri Üzerine Bir Değerlendirme, (Yayınlanmamış Doktora Tezi) Selçuk Üniversitesi, Sosyal Bilimler Enstitüsü, Ankara.

Artun, Erman (2013). Çukurova Halk Kültüründe Mizah, Adana: Karahan Kitabevi.

Bergson, Henry (1989). Gülme (Le Rire), (Çev. Mustafa Şekip Tunç), İstanbul: Milli Eğitim Bakanlığı yayınları.

Boratav, Pertev Naili (2013). 100 Soruda Türk Halk Edebiyatı, Ankara: Bilgesu yayınları.

Elçin, Şükrü (1986). Halk Edebiyatına Giriş, Ankara: Kültür ve Turizm Bakanlığı yayınları.

Morreall, John (1997). Gülmeyi Ciddiye Almak, (Çev. Kubilay Aysevener-Şenay Sayer), İstanbul: İris yayıncılık.

Özdemir, Nebi (2005). Cumhuriyet Dönemi Türk Eğlence Kültürü, Ankara: Akçağ yayınları.

Özünlü, Ünsal (1999). Gülmecenin Dilleri, Ankara: Doruk yayınları.

Sanders, Bary (2001). Kahkahanın Zaferi Yıkıcı Tarih Olarak Gülme, (Çev. Kemal Atakay). İstanbul: Ayrıntı Yayınları.

Sakaoğlu, Saim (1992). Türk fikraları ve Nasreddin Hoca, Konya: Selçuk Üniversitesi yayını.

Sakaoğlu, Saim (2013). “Geleneksel F1kra-Modern Fıkra”, Milli Folklor, Y11 25, S. 97.

Şimşek, Esma (2006). “Türk Tipleri Arasında 'Baskilli’ Fıkra Tipinin Yeri”, Mitten Meddaha Türk Halk anlatıları Uluslararası Bildirileri, Ankara: Gazi Üniversitesi THBMER yayını.

Şimşek, Esma (2015). “Türk Halk Edebiyatı Anlatı Türleri İçerisinde Fıkranın Yeri”, Akra Kültür Sanat ve Edebiyat Dergisi, S. 6 / Mayıs 2015.

Usta, Çiğdem (2009). Mizah Dilinin Gizemi, Ankara: Akçağ yayınları.

Yıldırım, Dursun (2016). Türk Edebiyatında Bektaşi Fıkraları, Ankara: Akçağ yayınları.

Yücebaş, Hilmi (2004). Türk Mizahçıları, Nüktedanlar ve Şairler, İstanbul: L\&M yayınları. 


\section{Sözlü kaynaklar:}

Derleme çalışmaları sırasında görüştüğümüz kaynak kişiler kimlik bilgilerinin yayınlanmamasını talep ettiklerinden künye bilgileri yazıya alınmamıştır. Kişilerin bilgileri ve ses kayıtları arşivimizde bulunmaktadır.

\section{Fıkra Metinleri}

\section{Örnek 1:}

Gercüşlünün biri sakal tıraşı için berbere gider. Gün boyu berber dükkânında su akmamaktadır. Berber göz açık biridir. Suyun akmadığını belli etmeden gelen müşterisine:

-Geçen gün bir Gercüşlü geldi o kadar delikanlıydı ki beni susuz ve köpüksüz tıraş et dedi ve tıraş bitene kadar hiç sesi çıkmadı.

-Ne demek, ben de susuz ve köpüksüz tıraş olabilirim, buyur beni de tıraş et.

Göz açık berber sakalı ıslatıp köpürmeden tıraş etmeye başlar. Bu arada yüzü kan içinde kalan Gercüşlünün canı yanmaya başlar. Berber hemen:

-Hayırdır sen Gercüşlü değil miydin? Sanki şikâyetçi gibi duruyorsun.

-Gercüşlüyüm dediysem merkezinden değil köylerindenim (K5-8).

\section{Örnek 2:}

Gercüş’te bir mağazanın açılışı yapılacak. Davetliler toplanır sıra kurdeleyi kesmeye gelir. Davetliler ve diğer bütün Gercüşlüler hep beraber makaslarını ceplerinden çıkarmış (K.1-6-7)

\section{Örnek 3:}

Gercüşlü biri eski model bir araba alır. Arabayla seyahat eden aile Gercüş'ün merkezine gelince temmuz sıcağında şoför camları kapatmış. Oğlu camları açmaya çalışınca, baba bağırmış "Eş.oğlu! Camı kapat arabamızın klimasız olduğunu anlayacaklar." demiş (K1-2-5-8).

\section{Örnek 4:}

Gercüş’ten on iki kişilik bir grup hacca gitmiş. Gruptan biri topluluktan kopup kaybolmuş. Adam gururuna yedirmediği için kaybolduğunu kimseye söyleyememiş. Gün boyu arkadaşlarını arayan adamın hareketlerinden şüphelenen biri ona durumu sorunca “On bir arkadaşım kayboldu. Onları arıyorum.” demiş3 (K3-5-7-8).

\section{Örnek 5:}

Gercüşlüler bir arabaya bindikleri zaman ağalığın verdiği gururla hep önde otururlar. Bir gün bir Gercüşlü Batman minibüsüne doğru koşmuş acelesi varmış bir bakmış ki

\footnotetext{
3 Farklı anlatılarda bu sayı 44 ve 99 hacı olarak geçmektedir.
} 
başka biri ön koltuğa oturmuş. Sadece arka koltuk boşmuş. Başka çaresi olmadığından arabaya biner. Araba Gercüş'e yaklaştığında şoföre silah çekerek "Arabayı geri sür." diyerek arabayı Gercüş merkeze girene kadar geri sürdürmüş (K4-7).

Örnek 6:

Adamın biri Gercüş'e gidiyor işini tamamlayana kadar akşam oluyor. Geciktiği için araba da bulamıyor hangi kapıyı çaldıysa kimse misafir olarak kabul etmez onu. Adam uyanık en sonda bir çare düşünür.

Bir evin kapısını çalar. İçerden bir kadın "Kim o?” diye seslenir. Adam da "Ağa evde mi?" diye sorar. Evin reisi "Ağa evde mi?" sorusunu duyunca hoşuna gider ve tok bir sesle hemen seslenip "Buyur gel gel” demiş(K1-5-6).

\section{Örnek 7:}

Gercüşlü bir köylü pekmez yapmış ve Siirt'e götürmek üzere eşeklerine yüklemiş. Beşiri taraflarına geldiğinde hem hava bozuk hem de yoğun bir sis varmış. Birinci eşek sisin içine dalıp kayboluyor. İkinci eşekte deniz gibi görünen sisin içinde kaybolunca adam üzülmüş. Uzaktan seyrederek "Vallahi, üzüntüm eşeklere değil de asıl üzüntüm pekmezedir.” demiş (K5-8).

\section{Örnek 8:}

Gercüş’te yakın tarihte ilk on katlı iki bina yapıldı. Tabi herkes herkesin ağasıdır. Kimse kimsenin eksiği değildir. En üst iki katta Gercüşlüler yerleşir. İlk sekiz kata ise dışar1dan gelen memurlar yerleşir. Dışarıdan gelenler kim oluyor da Gercüşlülerin üst katlarında oturacak (K3-7).

\section{Örnek 9:}

Şeyh Said isyanından sonra devlet ağaların fermanını çıkarır. Bir süre sonra ferman haberi Gercüş'e yetişir. Çıkarılan fermanda ağaların, şeyhlerin ve beylerin toplanması istenir. Çevrede yaşayan beş ağa Suriye'ye kaçıp af çıkınca geri dönmeye karar verirler. Bu ağalar Gercüş’ten geçerken şehir kenarda bir çoban ile karşılaşırlar. Çoban "Hayırdır! Nereye böyle kuşanmışsınız." diye sorar. Ağalar da "Biz ağayız ağaların fermanı çıkmış. Biz de kaçıyoruz." demişler. Çoban hemen kaftanı çıkarıp atar "Ben de sizinle geliyorum" der.

-Hayırdır sen niye geliyorsun?

-Ben Gercüşlüyüm, bütün Gercüşlüler ağadırlar (K2-5-6-8).

\section{Örnek 10:}

1980-90'lı y1llarda Gercüş’te işsizlik had safhadadır. Bir adam bir kamyon eşya getiriyor. Bunları indirmek için işçiye ihtiyacı vardır. Adam kahvehaneye girer, kahve tıklım tıklımdır. Adam kahveye seslenir.

-Arkadaşlar bir saniyenizi alayım. 
-Buyur.

-Bana üç-beş adam lazım.

-Ne yapacaksınız?

-Bir kamyon eşya var bunları indirmem gerekiyor. İşçiye, hamala ihtiyacım var.

Herkes ters ters bakıp oyunlarına devam ederler. Adam kahveciye döner şaşkın şakın sorar. -Bu adamlar ne iş yapar.

-Hepsi işsiz, boş gezen adamlar.

-Niye çalışmıyorlar.

-Bunlar ağa, amelelik yapamazlar (K2-6-8).

\section{Örnek 11:}

Gercüş’ün bir köyünden bir adam birkaç sepete şalgamı yüklemiş Gercüş’e getiriyor. Şalgamları yükten indiriyor. Sepetlerin en üstüne de en büyük ve düzgünlerini bırakmış. Eşeğini de yandaki ağaca bağlayarak pazarlık yapmak üzer bir bakkala gider. Sık1 bağlanmayan eşek ipini koparıp en üstteki güzel şalgamları yemeye başlar. Bunu gören köylü koşarak gelip okkalı bir tokat yapıştırarak eşeğin kulağını da sıkıca dişleyip şöyle der:

-Vallahi sen şalgamları bıraksan da ben senin kulağını bırakmam (K9).

\section{Örnek 12:}

Gercüşlü birinin inekleri akşam arpa deposuna girer ve çok fazla arpa yerler. Sabah ineği sağmak için inen çocuk bakmış inekleri o kadar arpa yemiş ki davul gibi şişmiş. Çocuk koşarak babasına seslenmiş.

-Bizim inek arpa yemekten fazla şişmiş nerdeyse ölecek. Eşekte hiç durmuyor durmadan zirliyor.

Bunu duyan babası ahıra bakar ve oğluna seslenir "Al bu parayı git dört beş soda al gel.” demiş. Birkaç soda ineğe verilince inek sakinleşir. Bu esnada eşek yine zırlar. Adam da eşeğe dönüp “ Seni gidi seni, sen de soda istiyorsun değil mi!” demiş (K3).

Örnek 13:

Üzüm zamanıdır. Gercüşlü bir çiftçi bağına gitmek üzere evden çıkar. Bağına gider bir asmadan güzel bir salkım koparmak için elini uzattığında aniden bir arı elini sokar. Can ağrısı havliyle bağırır çağırır tam üzüm salkımını yere çalacakken babası seslenir:

-Ne oldu? Ne yapiyorsun?

-Tam elimi bir salkım üzüme atacakken elimi bir arı soktu.

-Ben şimdi bu üzüm salkımını yere çakacağım.

-Oğlum sen bilmiyor musun bağların sahipleri Gercüşlüler değil aslında arılardır (K9). 


\section{Örnek 14:}

Bir gün Gercüş'ün alt tarafında bir çoban hayvanlarını otlatıyor. Bir bakıyor bir anda tüm Gercüş boşalıyor. Çoban hızla uzaklaşan insanlara doğru koşar ve birini durdurarak sorar:

-Hayırdır, hepiniz nereye kaçıyorsunuz?

-Ne olduğundan haberin yok mu?

-Haberim bir şeyden yok, Allah aşkına ne olmuş?

-Devlet ağaların fermanını çıkarmış ondan hızla Gercüş’ten ayrılıyorlar.

Bunu duyan çoban kaftanını çıkarıp hareketlenerek diğerlerine yetişmeye çalışır (K3-4-5-8).

\section{Örnek 15:}

Bir gün çoban Gercüş’ün kenarında hayvanlarını otlatıyor. Bir bakıyor ki şehirlilerin hepsi Mardin² yoluna girmiş ve hızla yürüyorlar. Birini durdurarak merakla sorar:

-Hayırdır, nereye böyle gidiyorsunuz?

-Mardin valisi haber salmış, ağaları Mardin'e davet etmiş.

Bunu duyan çoban da Mardin'e yönünü çevirerek yola koyulmuş (K1-6).

\section{Örnek 16:}

Gercüşlü biri evini Batman'ın merkezine taşır. Ev kiralar ve oturmaya başlar. Bir ay iki ay üç ay derken ev sahibine kirasını ödemez. Ev sahibi kiracıdan ses çıkmadığını görünce durumunu merak edip kirasını niçin ödemediğini sormaya gider. Ev sahibi Gercüşlü kiracısına sorar:

-Üç ay oldu kirayı ödemiyorsun, hayırdır inşallah niye kiranı ödemiyorsun?

-Şimdi sen benden ev kirası $\mathrm{m} ı$ istiyorsun?

- Tabii ki! Bedavaya mı oturacaksın?

-Yahu sen çevrene kiracının Gercüşlü olduğunu söyle. Bu şeref sana yeter. Nasıl para istersin benden (K3-7).

\section{Örnek 17:}

Gercüşlü biri satmak üzere eşeğine odun yükler ve gider. Gercüşlüleri iyi tanıyan bir alıcı çıkar.

-Ağa odunların kaç liradır?

-Al götür canın sağ olsun.

Adam odunları eve götürdükten sonra eşeği Gercüşlüye getirir ve teşekkür ederek ayr11ır. Eve dönünce babası ona sorar:

2 Batman il olmadan önce Gercüş Mardin'e bağlı bir ilçeydi. Bundan dolayı çok sayıda anlatıda Mardin merkez olarak anılmaktadır. Başka bir anlatıda Mardin valisi yerine Cizre Miri diye geçmektedir. 
-Oğlum odunları paraları nerede?

-Bir adam geldi “Ağa odunların kaç lira?” deyince para almadım.

-Tüh sana! Sen benim oğlum olamazsın. Ağa dedikten sonra sen eşeğini nasıl alırsın utanmaz.

\section{Örnek 18:}

Gercüşlünün biri milletvekilli seçilir. Ankara'ya hem yemin töreni hem de mazbatasını almak üzere gedecek. Tabi özel araba, şoför ve koruma da verirler. Her seferinde koruma arka kapıyı açıp "Buyurun sayın vekilim!” deyip arabaya buyur eder. Vekili mecbur bırakıp arkada oturturlar. Vekil bakıyor Ankara’ya da az kaldı ama bir türlü öne geçemiyor. Ankara yakınlarında ulaştıklarında vekil "Ankara' ya girmeden bir dinlenme tesisine çekin.” der.

Herkes ihtiyaç için arabada iniyor. Milletvekili firsattan istifade hızla koşup öne oturur:

-Milletvekili de olduk bunlar yine beni arkada oturtuyorlar (K10).

\section{Örnek 19:}

Gercüş'e yabancı biri geliyor. Geç saatlere kadar işi ile uğraşıyor şehirden ayrılmak için araba bulamayınca bir kapıyı çalar ve "Ben tanrı misafiriyim." der. Adam da eşinden ceketini ister ve adama bir açıklama yapmadan beni takip der. Adam da merakla takip ediyor onu. Tam caminin önüne gelip "Sen Tanrı misafirisin buyur bu da Tanrının evi." $\operatorname{der}(\mathrm{K} 10)$.

Örnek 20:

Gercüş'ün bir köyüne Gercüşlü fahri bir imam görevlendiriliyor. Köylüler de bir süre sonra imama:

-Seyda, hizmetin karşıllğı olarak bizden ne isteyeceksin?

-Yılda bir kere her evin üzümünden yüzde on isterim.

Köylüler de bu kolay iştir deyip bir yıl geçmesini beklerler. Yıl geçip üzüm vakti geldiğinde herkes sepetlerle üzüm getiriyor. İmam bütün üzümü eve alıyor. Köylülerden biri imamın bu kadar üzümü ne yaptığını merak eder ve sormaya karar verir.

-Seyda sen bu kadar üzümü ne yapacaksın?

-Birazını yemek için ayırıyorum, birazını da kursa gelen çocuklara veriyorum, kalanı da ziyan olmasın diye küpe basıp toprağın altına saklıyorum (K10). 